DOI https://doi.org/10.36059/978-966-397-113-1/284-301

\title{
ADMINISTRATIVE LAW REFORM IN THE CONTEXT OF HUMAN RIGHTS
}

\section{Petkov S. V.}

\section{INTRODUCTION}

Forming a democratic, social and law-governed state in Ukraine requires bringing a system of Ukrainian law in compliance with such principles on which the respective systems of developed countries around the world are based, in particular, in European countries. Considering the issue of adjusting of Ukrainian law to European standards, one should say about the dualism of law, that is, its division into private and public, which, although not officially consolidated, in fact, exists in Ukrainian law.

The dichotomy of law, with its division into public and private law, was substantiated theoretically in ancient Rome. It was Roman lawyers who believed that this division was natural because it reflected the comprehensible features and differences of relation between the state and a private individual. The essence of such division is an interest which is protected a legal order.

Public and private law as two parts of one whole are interconnected and at the same time we can clearly distinguish them. The functions they perform are ultimately in the interests of everyone. Public law is intended to defend and protect private relations. Private law creates the material basis for the existence of the state that protects public institutions, families, property, inheritance, etc. Today, both public and private law remain the fundamental source of a truly democratic legal system.

When leading lawyers from foreign countries traditionally developed the democratic foundations of legal systems in their countries for a long time, at the territory of Eastern Europe revolutionary events took place that interrupted the gradual development of legal thought and led to the legal justification of totalitarian regimes.

Wrong understanding of terms and relations regulated by two components of civil law, namely public and private law, created the conditions for the transformation of administrative law into punitive law. As a result, and due to the internal unity of administrative law, it turned, 
in accordance with the Soviet model of public relations, into law that regulates all domains of public life, including the private law relations in the domain of economic activity. In the Soviet period of development of law there was neither possibility nor sense in any research on this issue, because the dualism of law was not recognized officially. The norms on administrative responsibility of officials - managers of factories, plants, etc., could only arise in the legal system serving a militarized society, where heads of institutions and departments had military ranks and executed secret, military tasks, where enterprises and even entire cities were classified, etc. Only after reformation and choosing a course on the construction of a law-governed democratic state by post-totalitarian countries the works dedicated to this issue appeared ${ }^{1}$.

As A. Kolodiy rightly notes, the field of public law should be regarded as vertical relations (administrative), relations of subordination, power - subordination. Their regulation should be carried out on the principle of imperative nature, and the rights and obligations of the subjects should be formulated explicitly and comprehensively in law. A scholar defines the field of private law as a set of horizontal relations that provide for an equal position with respect to independent subjects. They are governed by the principle of discretion nature, and the subject themselves, within the framework of law, establish their rights and obligations $^{2}$.

\section{The Reformation of Public and Private Legal Relations}

Performing the role of public relations regulator, the state always tends to reach their maximum number, even where mere private interests are realized. However, compliance with the balance of "regulation" and "non-interference" on the part of the state is an indicator of a democratic law-governed state with market economy. Therefore, any relations in the field of economic activity are regulated. And their public activity in the field of economic activity, in the field of profit etc. was under the state monopoly - there were no private companies, institutions, organizations as a class.

Nowadays, we still experience the echo of the Soviet approach to regulating public relations. The Code on Administrative Offenses of

\footnotetext{
1 Адміністративне право України. Академічний курс: підручник: у 2 т. / ред. колегія: В.Б. Авер'янов (голова). - К. : Юридична думка, 2004. - Т. 1. Загальна частина. - С. 132-133.

${ }^{2}$ Колодій А.М. Принципи права України / А.М. Колодій. - К., 1998. - С. 66.
} 
Ukraine contains a large number of norms that provide for the responsibility of private law subjects for violating rules, legal norms, standards that have no relation to the state administration.

The distinguishing of an individual branch of law, namely, economic law was a great step towards the denationalization of the part of legal relations and their adjustment in accordance with the world standards. However, there are still discussions about its nature and place in the system of law, considering that it is the administrative and legal field of public relations where the economic law has taken its origin. Thus, some scholars strongly affirm that the existence of economic law as an independent branch of law is justified (V. K. Mamutov, V. V. Laptev, I. G. Pobirchenko, at al.). Other scholars (S. Bratus', R. Khalfina, G. Matveev, Y. Shevchenko, A. Dovgert, at al.) consider that the economic law is not an independent branch of law, but rather a combination of civil and legal, administrative and legal norms in the field of economic activity.

There are some views that economic relations can not be divided into civil-legal and administrative-legal, although the historical roots of economic law is in the field of both public and private law. Moreover, economic law has a significant share of its own regulatory material, which does not belong to either civil or administrative law. The institution of bankruptcy is one of such institutions led to the separation of economic (trade, commercial) law in a separate branch of law ${ }^{3}$.

Moreover, there is a scientific position, according to which, within the branch of administrative law should be distinguished sub-branch, namely, administrative-economic law. "The need for the emergence and development of administrative-economic law is explained by the need to put in order public relations that arise between economic entities. Both the said entities and the state are interested in regulation of such relations, since today the economy is fundamental to provide the existence of the country population and a constant increase in its standard of living. Therefore, legal norms are being developed and adopted at the state level

3 Мандриковський М.М. Господарське законодавство: Навч. посібник. - Львів: Вид-во Нац. ун-ту “Львівська політехніка”, 2004. - 172 с.; Пігач Я.М., Труфанова Л.М.: Господарське законодавство: Навчальний посібник. - К.: Центр навчальної літератури, 2005. - 624 с.; Беляневич В.Е. Науковопрактичний коментар до Господарського процесуального кодексу України / В.Е. Беляневич. - К. : Видавництво «Юстініан», 2008. - 872 с.; Притик Ю.Д. Науково-практичний коментар до Господарського-процесуального кодексу України / Ю.Д. Притик. - К. : Центр учбової літератури, 2011. $-719 \mathrm{c}$. 
that should contribute to the development of the national economy. In fact, these norms form administrative-economic law".

It is not possible to ignore the trend to crystallization of a new approach to understanding the system of law based on the legislation system. The division of the law in branches and sub-branches introduced in the Soviet legal doctrine is not always consistent with the requirements of time. At that time, in many European states, the law was developing on the foundations of Roman law. In French legal science, it is divided into two specialties: public and private ${ }^{5}$. This way, new branches of law have appeared: information law, banking law, financial law, tax law and others. In fact, they are more close to the notion of "a branch of legislation" than "a branch of law". After all, public law and private law relations, methods, as well as regimes are "mixed" in them. Scientific developments from other sciences and applied disciplines such as economics, mathematics, statistics, and others have gained a great significance in them.

Dozens of thesis studies, the subject of which are economic-legal relations, regulation of social processes in the state, show, on the one hand, that today administrative law has become a kind of catalyst for the transformation of both public relations and the scientific and legislative components of law as a phenomenon. This process is already taking place. And scholars should not be aside, but rather explore and develop the latest approaches. We already have a positive experience in the emergence of such scientific schools: "tax law"- M. P. Kucheryavenko, "medical law" - S. G. Stetsenko, V. Y. Stetsenko, "information law" K. I. Belyakov, R. A. Kalyuzhny, I. V. Aristova, "customs law"D. V. Priimachenko, Y. D. Kunev, B. A. Kormych and others.

Now it is clear that the economic activity of an economic entity, regardless of ownership, whether it is a private firm, or a public institution, should be governed by legal norms of private law. Payment of utility bills as well as payment of wages, etc. is manifestation of economic activity. Therefore, economic law is a part of private law ${ }^{6}$. This way, the

4 Мельник Р.С. Адміністративно-господарське право як структурний елемент системи адміністративного права: зарубіжний досвід та національні особливості / Р.С. Мельник // Право і Безпека : науковий журнал. - 2010. - № 2 (34). - С. 34-37.

5 Головко Л.В. Вступительная статья / Кабрияк Р. Кодификации / Пер. с фр. Л.В. Головко. - М. : Статут, 2007. - С. 12.

6 Хозяйственное право Украины: Учебник / Под ред. А.С. Васильева, О.П. Подцерковного. Харьков: ООО “Одиссей", 2005.- 464 с.; Хозяйственное право: Учебник / В.К. Мамутов, Г.Л. Знаменский, К.С. Хахулин и др.; Под ред. Мамутова В.К. - К.: Юринком Интер, 2002. - 912 с.; Щербина В.С. Господарське право: Навчальний посібник. - К.: Вентурі, 2004. - 288 с. 
legal relationships and responsibility for their violation can not be regulated by administrative legislation. The norms governing responsibility for the misconduct in the field of economic activity must now be classified as "Economic misconduct" in economic law, as it was with customs misconduct.

The activity of legal entities not related to the exercise of powers in the public law field is not state management, and therefore can not be an administrative activity. Mostly, it is an economic activity, which is regulated by economic law norms. It is mostly economic activity regulated by economic and legal norms. The responsibility of economic legal relation entities, which is currently established by the Code on Administrative Offenses of Ukraine, should be stipulated by the Civil, Commercial, and Commercial Procedural Codes ${ }^{7}$. And thus, the legal norms should be transferred from the Code on Administrative Offenses of Ukraine to codification acts of the relevant branch. E. V. Pogorelov emphasizes that "the formation of civil society requires the extension of the field of private law and reduction of public law"8.

\section{Systematization as the Basis for Improvement of Applicable Codes}

Administrative law is the classical branch of public law. However, the legal norms of this branch are closely related to other branches of both public and private law. French professor Guy Braibant noted that administrative law regulates the organization and functioning of the state management apparatus, its relations with individual citizens, but does not regulate the following: a part of work of administrative structures provided by norms of civil law; formation of a policy - it is considered the prerogative of the parliament, the government or the head of state and falls under the scope of constitutional law; judicial activity in resolving disputes between citizens (civil-procedural) and bringing to justice those who committed crimes (criminal procedural law) ${ }^{9}$.

The pyramid structure, in which the constitutional law is at the top, the administrative and criminal law is at lower level, then the labor, land, customs, economic law, etc., is stable and unshaken. In such system it is difficult to find a place for an average citizen who is constantly under

\footnotetext{
${ }^{7}$ Господарський кодекс України. Господарський процесуальний кодекс України: Офіційні тексти / Міністерство юстиції України. - К.: Юрінком Інтер, 2003. - 304 с.

${ }^{8}$ Погорєлов Є.В. Кодифікаційна діяльність в правовій системі України (загальнотеоретичний аспект). дисертація на здобуття наукового ступеня кандидата юридичних наук. - Харків - 2000. - С. 68.

${ }^{9}$ Школик А.М. Порівняльне адміністративне право : навч. посіб. - Львів: ЗУКЦ, 2007. - С. 25-26.
} 
pressure from the authorities and laws. However, the authoritative, hierarchical and pyramidal structure is gradually deepening into problems and unresolved conflicts.

We are not going to stop and criticize a range of modern concepts born on the basis of scientific searches in detail, as they are not based on the achievements of legal science. Obviously, patriarchal approaches to the formation of scientific schools, the destruction of opponents with the help of status and ties can not be considered normal. In addition, attention has been consistently paid to a low level of thesis research, plagiarism and compilation in a number of scientific works, which is in fact unacceptable, in the publications on pages of scientific reviews as well as in the orders of the Ministry of Education and Science.

By such actions and counteractions two things take place that negatively influence the development of science. Firstly, a number of pseudo-humanistic approaches to administrative law are being developed, discussions on the administrative responsibility of legal entities are continuing, the whole branches of law are being created with their subbranches, but without their own methodological approaches, mechanisms, etc. Secondly, there is a "pressure" on all the latest scientific ideas and stories in the legislation of the authors who do not have the proper "weight" in the "scientific world".

At this certain time in administrative legislation there is a complete disharmony, a number of legal norms simply contradict the elementary logic. In fact, such norms "do not work" at all. They are called useless. However, they still remain in force. Even their presence prevents the state from developing but without understanding the reasons for their appearance in legislation it is dangerous to cancel them. In this context, the purification of legislation from alien layers and outdated approaches should be based on conceptual doctrinal approaches to law. A measure and a standard of legislative activity should be the Constitution, as the Basic law of the country.

Analyzing legislation, the important stage is incorporation (lat. Incorporatio - accession) - a kind of normative act systematization, which consists in bringing them into collections in a certain order without changing the content of normative acts. One should define the field of public relations as the criterion for systematization in the form of incorporation. 
At present, it is necessary to speak about the branches of legislation located in one horizontal plane. We would like to emphasize that the branches of legislation is a conditional denotation of certain parts of the country's legal system. Laws should regulate certain areas of public life; therefore, the question of merging branches of law and branches of legislation, areas of public life, which are now in constant transformation should be raised.

These branches are large groups and have their own codes. Institutions, sub-institutions are connections between branches, enshrined in laws. In the same way, the issues of activities of certain state institutions, ministries and agencies should be consolidated by the laws but in no case by orders and decrees. The legal norms (as a cementing substance) run through all the components of this construction. It is only possible to build the law-governed state on such solid monolithic foundation.

At present, in Ukraine there are some legal acts that were adopted during the Soviet period of the state existence and are still in force. In many cases, they do not correspond to the realities of the present. Standards, GOSTs (state standards), operating manuals have sometimes remained behind scientific and technological progress for decades. By their number and inconsistency, they distract the attention of both controlling bodies and society from the level of observance and protection of human rights and freedoms in relations with the subjects of powers. In such a situation, a detailed revision of the existing legal and regulatory framework in all domains of socio-economic life is required.

Systematization of legislation is an activity aimed at sorting out the current normative legal acts in a single agreed system, in order to ensure effective legal regulation. There are the following types of systematization: accounting, codification, incorporation and consolidation.

Systematization is aimed at achieving the internal unity of legal norms, that is, to eliminate conflicts and gaps, which increases the effectiveness of legislation and putting in order the legal material, placing it in certain sections and headings, that is, a classification providing the convenience of using the legislative data sets. Systematization can be internal and external. The purpose of internal systematization is the internal processing of normative acts, contributing to the achievement of 
the internal unity of legal norms. The purpose of external systematization is the external processing of normative acts, their classification.

The systematization is made in four ways:

-Accounting (magazine, card, electronic) - collection, settlement in logical sequence and storage of normative legal acts, keeping them in the appropriate control (current) state, taking into account all changes and amendments, as well as creation of special systems for their accumulation and search;

- Incorporation - uniting a group of valid legal acts in one collection according to a certain criterion (chronological, thematic, etc.) without changing their content;

- Consolidation - a kind of systematization in the process of which several acts are combined in a new document. In the process of consolidation, the law-making body creates a new legal document, which completely replaces the previous one; all normative provisions of previously adopted acts are united in it without changes, although, as a rule, their editorial correction is made: contradictions are eliminated, as well as repetition, etc. In countries of the Romano-Germanic legal system, consolidation performs only an auxiliary role (eliminates the plurality of new legal acts, their extreme fragmentation, and duplication). However, it is actively used in countries of common law;

-Codification is a meaningful processing, coordination and consolidation of a certain group of legal norms related to the common subject of legal regulation, in a single normative act.

The purpose of incorporation is to prepare the current legislation to codification and construction of a logically structured system of legislation. This is also improvement of communicative codes, incorporation of the adopted laws into already existing codified acts, codification of laws regulating one socio-economic domain, changes, amendments and additions to codes.

There are some types of incorporation:

-In accordance with legal significance: official incorporation, that is, putting in order regulatory acts by publishing the collections of applicable legal acts (for example, the publication of laws in the Bulletin of the Verkhovna Rada of Ukraine, amendments and additions) by law-making competent authorities or authorized competent authorities by them; unofficial incorporation is the preparation and publication of collections 
of current normative legal acts by non-law-making state bodies or other organizations or individuals.

-In accordance with a scope: common (general); branch; interbranch; special (by specific institutions of one law branch).

- In accordance with the criterion of unification of normative and legal acts: objective, that is, by object of regulation; chronological (by the time of normative legal acts publication); subjective (depending on the body issued the acts).

Incorporation (lat. Incorporatio - joining) is a kind of normative acts systematization, which consists in consolidating them in collections, in a certain order without changing the content. The field of public relations should be the criterion for systematization in the form of incorporation.

At present, it is necessary to speak about the branches of legislation, located in one horizontal plane. We would like to emphasize that the field of legislation is a conditional definition of certain parts of the country legal system. Laws should regulate well-defined areas of social life; therefore, the issue of merging the branches of law and the branches of legislation, the areas of public life, being now in a constant transformation, should be raised. These branches are large groups and have their own codes. Institutions, sub-institutions are connections between branches, enshrined in laws. In the same way, the issues of activities of certain state institutions, ministries and agencies should be consolidated by the laws but in no case by orders and decrees. The legal norms (as a cementing substance) run through all the components of this construction. It is only possible to build a legal state on such solid monolithic foundation.

The whole range of legal acts that was adopted during the period of state existence and is still in force and scatters the attention of both controlling bodies and society from the level of observance and protection of human rights and freedoms in relations with the subjects of powers.

The most demonstrative example of incorporation can be collections of normative and legal acts governing labor relations ${ }^{10}$. Especially since labor law is closely associated with administrative law in relation to general issues in the work relation regulation. Those who are not subject

\footnotetext{
${ }^{10}$ Кодекс законів про працю України. - К., 2008. - 124 с.; Про порядок вирішення колективних трудових спорів (конфліктів) : Закон України від 03 березня 1998 року № 137/98-ВР // Відомості Верховної Ради України. - 1998. - № 34. - Ст. 227; Про відповідальність суб’єктів підприємницької діяльності за несвоєчасне внесення плати за спожиті комунальні послуги та утримання прибудинкових територій від 20 травня 1999 року № 686-XIV // Відомості Верховної Ради України. - 1999. - № 29. - Ст. 240.
} 
to the Labor Code and collective agreements are regulated by the norms of administrative law (conditions of entry into service, the record of service, the rules of keeping official documents, the assignment of special personal titles, ranks and grades, and other issues that constitute organizational activity state in the field of work relations $)^{11}$. The connection of labor law with administrative law is also manifested in the training of personnel. The whole system of training of blue collar workers and specialists, excluding the training of workers and the retraining of specialists at the production directly, when the student agreement can be concluded as a kind of labor contract, is the subject of administrative law regulation.

We should emphasize that law in the field of civil servant labor, officials, state power bodies, law enforcement bodies etc. requires improvement. The main thing is to determine the status of employees and officials exactly as the participants of a particular type of labor process (for example, the regulation of the right to remuneration for work, for vacation, for social insurance). At the same time, a certain interweaving of norms of labor and administrative law can be observed. For example, labor law governs everything directly related to the work of a citizen. However, registration to work, powers of the administration in the field of service by employees of state bodies, that is, all that is manifestation of managerial functions are governed by the legal norms of administrative law.

Labor legislation governs the part of relations that ensures the realization and protection of labor rights and interests of the subjects of administrative law relations. Civil servants are subject to special disciplinary responsibility. On the other hand, the area of labor law includes organizational-legal relations, since in regulation of the labor process the relations of power are acting such as subjection, similar to the administrative-legal regulation. The legislation establishes responsibility for violating the requirements of labor legislation and the protection of labor, for avoiding participation in negotiations on the conclusion, amendment or addition of a collective agreement, consent ${ }^{12}$. Among the

\footnotetext{
11 Якуба О.М. Советское административное право (Общая часть) / О.М. Якуба. - К. : Вища школа, 1975. - C. 38.

12 Жарков Г.М. Трудове право України: підручник. - К.: Ленвіт, 2007. - 428 с.; Трудове право України: Підручник / За ред.. Н.Б.Болотіної, Г.І.Чанишевої. - К.: Т-во «Знання», 2000. - 564 с.; Дмитренко Ю.П. Трудове право України : підручник / Ю.П.Дмитренко. - К.: ЮрінкомІнтер, 2009. 624 с.; Трудове право України Навчальний посібник / За ред П. Д. Пилипенка - К.: Істина, 2005 -208 с.; Трудове право України: Академ. курс: Підруч. /А. Ю. Бабаскін, Ю. В. Баранюк, С. В. Дріжчана та ін.; За заг. ред. Н. М. Хуторян. - К.: Видавництво А.С.К., 2004. - 608 с.
} 
types of penalties are corrective works that take place at the place of fulltime work of the person who committed the offense ${ }^{13}$.

Such theoretical accumulation has already led to the complication of legislation that requires fundamental changes. Therefore, it is necessary to return to the essence of certain public relations governed by law. And if we are talking about the fact that service is a kind of work, then the issue of registration for service, attestation, dismissal, and retirement provision should be considered within the framework of labor law as special aspects of legal relations in the field of labor.

Actually, scientists and practitioners are moving in this direction, creating a collection of legislation on labor, which clearly demonstrates the current state of the branch and is easy to use in law enforcement practice. One should mention among these, a collection with incorporation elements of the publishing house "The Center for Educational Literature" - "Labor Relations. Legislation, international conventions, judicial practice, methodical recommendations, clarifications". ${ }^{14}$ It contains international and national normative legal acts in the field of labor relations, enabling determination of the degree of Ukrainian legislation compliance with the international standards, revelation of possible collisions and gaps in current law. It is considered that in the future, when carrying out codification of legislation in the labor relation field, such collections will play a system-forming role, the role of the basis on which the renewed legislation will be based.

\section{Codification as an Ultimate Goal in Reforming Legislation System}

Effective legal support for administrative reform involves further systematization of administrative legislation, primarily through its codification. It is always associated with deep and comprehensive processing of the current legislation and making significant changes to it. The codification provides internal coherence, integrity, systematicity and completeness of legal regulation of the relevant relations.

Today it should be noted that in the administrative law of the postSoviet period there were tectonic changes. The whole continent of the theory of state administration broke off from the general set of administrative law. It is at a time when the relations in state administration

\footnotetext{
13 Трудове право : підручник / під ред. В.В. Жернакова. - Х. : Право, 2012. - 496 с.

14 Трудові відносини. Законодавство, міжнародні конвенції, судова практика, методичні рекомендації, розяснення. Практичний посібник / Григоренко. - К. : Центр навчальної літератури, 2016. -344 c.
} 
are the subject of administrative law study. However, such shift has led to other consequences. In the depths of administrative law, new legal branches have emerged: financial, information, customs, and medical law. They are developing dynamically and in the scientific and practical sense, they have achieved significant results. And this in turn contributes to the new cyclic-like movement. Namely: scientists state that there is a dual nature in these sectors: public and private. Thus, they can not be part of the administrative law. Administrative law is purely public. Is there any contradiction? - Not at all.

We can look at the very list of so-called administrative (managerial) misconduct: Art. 45 "Evasion of examination and prophylactic treatment of people with STD», Art. 178 "Drinking of beer, alcoholic, low-alcohol beverages in places prohibited by law or appearing drunk in public places", Art. 176 "Manufacture, storage of home-made alcohol and apparatus for its production". However, administrative responsibility is the managerial responsibility, that is, the responsibility of the person, entitled by the authorities with powers and the corresponding administrative-legal status. While in most articles we can see public legal relations not related to non-fulfillment or improper fulfillment of their duties. Obviously, in this case, a person can not bear the administrative (managerial), responsibility because they are not the subject of powers of authorities; do not perform the relevant administrative functions.

We can see that the legislation ignores the elementary basic provisions of the law theory. However, other illogical things happen too. The essence of a phenomenon is in the following. Representatives of certain departments, business groups, deputy assistants, etc., develop novels to the law according to their "worldview approaches". The quality of such novels is evidenced by a series of economic and political crises that have shaken the last thirty years of the post-Soviet state. It is sad, but today monographs and textbooks on the law turned into a list of eminent scholars and their views "on the subject" in combination with commentary on legislation. At present, it is not practice that is based on scientifically proven postulates, verified by time, but scientists justify and "support" regulatory acts theoretically.

We emphasize that the basic foundations of law are unchanged despite changes in public relations. This applies both to law in general and administrative law in particular. Therefore, reviewing the foundations of legislation, one should rely, firstly, on the basic postulates of law, and 
secondly, take into account the changes that have taken place in society the change of the socialist system to the capitalist one.

Attempts to answer complex questions related to the redesigning of public relations under the latest conditions are made by scholars based on modern concepts, the essence of which is the fractal paradigm of building fields, institutions, branches, etc. Alexey Almazov in his book "Fractal Theory. How to change the view of markets", suggested the use of fractals in the analysis of stock quotes, Andrew Morrison Stumpf analyzes legislation from fractal positions in his work "Legislation is a fractal: an attempt to anticipate everything".

Administrative law is one of the elements of a holistic system. As well as other parts of the law, administrative law is modified according to the general rules of the system existence, and therefore the transformation of administrative law can be predicted, analyzed, and calculated. And, accordingly, some inconsistencies can be found in them as well as contradictions can be eliminated, and so on.

The algorithmic method implementation is possible at all levels of jurisprudence, in scientific dimension for cognition of the essence of legal phenomena, in law-making for improvement of existing formulas (norms, laws) and the proof of new law enforcement and judicial authorities in the enforcement activities for the proper resolution of disputes that arise between different subjects of legal relations. Just as other sciences cognize the world around with various methods, instruments, reagents, etc., the law science studies relations in society. A large number of questions remain beyond our cognition in both natural sciences and social branches. We can not fully predict the consequences of one or another of our actions. Many issues have previously remained; others have still remained outside the law. What was previously normal for a society, such as cutting scalps, is now disapproved. And if earlier actions of the ruler, even if they were immoral, were perceived as a manifestation of God's will, now they cause the condemnation of society.

Codification is the most perfect form of legislation systematization. The legal purpose of codification is to get in order the normative basis of law, to ensure the most effective process of law implementation, to improve the structure of codification acts, to improve their logic, language, and style. Usually, codification (as opposed to incorporation) is based on the system of law, although it can not completely coincide with it. 
Codification is an essential system-creating and stabilizing factor of the entire legal system and it contributes to the organized development of law, fills it with common principles, general legal concepts and categories. Adoption of codification acts as a result of codification is aimed at strengthening the element of stability in the legislation and the formation of a stable normative and legal framework.

Codification is the sorting out of legal norms, accompanied by the reviewing of their content, with the cancellation of some and the adoption of other legal norms, which is possible only in the process of law-making. As a result of the codification issued a single, logically and legally integral, normative legal act. Therefore, codification always has an official nature and can be carried out only by the law-making body.

Today norms, formed in the depths of administrative law in the period of the state-centered approach greatest development, are playing a role of a synergistic catalyst in the formalization of legal norms in various socio-economic domains. The emergence of a new system of Ukrainian law with division in accordance with the areas of application: medical, fire-preventive, construction, sports, etc., as science, as legislation, as a practical right-exercising activity, has now been fully in line with the realities.

Codification is the activity carried out by law-making bodies.

There are the following types of codification:

- by volume: general, as a result of which a codified normative act is created on the main branches of law (a code of laws); branch, covering regulatory legal acts of a certain branch of legislation (the basis of legislation, codes); inter-branch and sub-branch (institutional), which covers several branches (Air Code) or institutes (Customs Code) accordingly.

- By the form of expression: basics (main principles) of legislation; codes; provisions; chapters.

Codification legal acts are divided into:

- Basics of legislation: codification act, containing the most common norms and stipulates goals and principles of legal regulation of a certain group of social relations;

- The code - a single, consolidated, legally and logically holistic, internally agreed normative legal act that ensures the regulation of public relations in the relevant branch or sub-branch of legislation. 
Unlike the norms of some law branches, it is impossible to unite all norms of administrative law in one or even in several complex (codified) acts for objective reasons. Administrative law governs a wide range of public relations. It contains norms in numerous acts of various legal force. Moreover, norm-making in the administrative field is characterized by a high level of dynamism, frequent emergence of new norms, complicating the content and structure of legal material and limiting the possibility of its codification.

It should also be kept in mind that one or another branch of law, unlike the branch of legislation, should not have "personal" codes. For example, procedural law covers all activities of state bodies, economic and other activities. One or another code may "cover" several branches of law. Thus, licensing law regulates the issue of licenses for the extraction of minerals, the sale of medicines, etc., and the permissive law regulates the use of weapons, the vehicles driving, and permission for certain activities. They are closely linked with each other.

There is a range of codes: the Customs Code, Tax Code and others. It is extremely necessary to systematize legislation on public health. The structure and content of the Medical Code have been already given in a number of studies. Leading scholars and practitioners emphasize the creation of the Road Traffic Code and the Registration Code. The main difference of the updated legislation will be its compliance with modern standards and algorithms of the law theory. Thus, it is necessary to adhere to the principle of the norm updating in the structure of each normative act, so the hypothesis, disposition and sanction will be contained in one codification act. Certain studies of the area mentioned in systematization of administrative legislation in the form of its codification, have been discussed in the works of leading and young scientists more than once ${ }^{15}$. The necessity in adoption of the Electoral Code has already been emphasized repeatedly. It is to the code mentioned where misconduct against the electoral rights of citizens must be transferred ${ }^{16}$.

\footnotetext{
15 Народний суверенітет, як основа адміністративно-правової реформи в Україні: навч. посіб.; за заг. ред. В.П. Пєткова. - К. : Дакор, 2012. - 216 с.; Безпека дорожнього руху в Україні: : навч. посіб.; за заг. ред. В.П. Пєткова. - К. : Дакор, 2012. - 488 с.; Народне волевиявлення в Україні : навч. посіб.; за заг. ред. В.П. Пєткова. - К. : КНТ, 2012. - 144 с.; Санітарно-епідеміологічна безпека : навч.посіб.; за заг. ред. В.П. Пєткова. - К. : Видавничий дім «Скіф», 2013. - 128 с.; Екологічна безпека : навч.посіб.; за заг. ред. В.П. Пєткова. - К. : КНТ, 2013. - 216 с.; Реєстраційне право: навч. посіб.; за заг. ред. В.П. Пєткова. - К. : Дакор, 2012. - 216 с.

${ }^{16}$ Циверенко Г.П. Народне волевиявлення в Україні : навч. посіб. / Г.П. Циверенко. - К. : СКІФ, 2012. -144 c.
} 
And it tells about the global processes of systematization (incorporation and codification) taking place in our country. Significant changes have also occurred in the administrative law itself, both at the territory of Ukraine and at the whole post-Soviet space, and even in the leading countries of the world. Such processes are fully consistent with old legal tradition and modern world practice ${ }^{17}$.

It should be done for the formation of modern legislation that will govern public-legal relations in accordance with modern world standards and constitutional provisions. In addition, the norms and a number of different by-laws will find their place in the legislation during the codification, which will simplify their application.

In total, due to a definite approach to public law, we will achieve the following goals: humanization of the legal system, compliance with the provisions of the constitution of Ukraine. So, the law will correspond to the essence of civil law. Simplicity and clarity of laws for citizens will affirm the democratization of society.

Due to increased tension in society, an increase in the number of misconduct by citizens in all domains of socio-economic life, deterioration of public attitudes towards public authorities, and reduced manageability both in the system of state authorities and from public authorities by social processes taking place in the country, there is an urgent need for the country to update the normative and legal framework for the activity of state power bodies and make them comply with the world standards.

For example, in order to ensure public safety and public order, there are many rules and norms of behavior established by normative and legal acts of various levels, namely, the Fire safety rules, Regulations on the organization and conduct of mass events, the Law of Ukraine "On measures for the prevention and reduction of the tobacco product use and their harmful effects on the health of the population" and many others. Due to its quantity and incoherence of tort norms, it produces conflicts and difficulties in their application. So bringing the rules of conduct in society and the bases of responsibility for their violation to a single standard enshrined in one normative legal act will greatly increase the effectiveness of the protection and maintenance of public order. The solution to this is adoption of the Code of Ukraine on public order, which

\footnotetext{
${ }^{17}$ Кабрияк Р. Кодификации / Пер. с фр. Л.В. Головко. - М. : Статут, 2007. - 476 с.
} 
will facilitate the development of Ukrainian legislation in the filed of administrative principles of the protection of human rights and freedoms, in accordance with world standards, and education of citizens in a spirit of respect for the law and the state.

\section{CONCLUSIONS}

Public authorities are required to direct their regulatory influence in full on the private law sector, including economic and legal relations. Administrative law should ensure favorable and equal conditions of operation for all business entities and their protection from negative influence from any side, including from the state.

The system of granting licenses, permits, conducting registration, etc., requires radical changes in the direction of information provision and simplification of procedures. Firstly, it should be regulated as much as possible. The submission of documents should be based on the "Single window" principle, when a limited number of documents are submitted for permission to the relevant institution. For example, a title document, an application and a certified identity card. And the issue is solved within a short time - a day or a week. Secondly, there must be transparency of actions, openness of registers, system of state protection of personal data, key system and admissions to information bases. Thirdly, removing of unnecessary red tape of legal relations. Transfer of a number of functions to non-state institutions and organizations. It concerns insurance, pension, property protection, etc.

Effective legal support for administrative reform involves further systematization of administrative legislation, primarily through its codification. Since it is objectively impossible to codify the norms of administrative legislation at the same time and in one act, it is reasonable to carry out step-by-step codification of certain domains and institutions of administrative-legal regulation. Today, it is necessary to create new regulatory laws for the proper functioning of socio-economic areas. The codification of existing rules, norms, orders, and standards governing the socio-economic area in one communicative normative legal act is the need of the present. We emphasize that sorting out of administrative law should be carried out through the issuance of codified acts for certain domains and institutions of administrative and legal regulation. 


\section{SUMMARY}

The article deals with the issue of administrative law reform in the context of human rights. Forming a democratic, social and law-governed state in Ukraine requires bringing a system of Ukrainian law in compliance with such principles on which the respective systems of developed countries around the world are based, in particular in European countries. Considering the issue of adjusting of Ukrainian law to European standards, one should say about the dualism of law, that is, its division into private and public, which, although not officially consolidated, in fact, exists in Ukrainian law.

Effective legal support for administrative reform involves further systematization of administrative legislation, primarily through its codification. Since it is objectively impossible to codify the norms of administrative legislation at the same time and in one act, it is reasonable to carry out step-by-step codification of certain domains and institutions of administrative-legal regulation.

The system of granting licenses, permits, conducting registration, etc., requires radical changes in the direction of information provision and simplification of procedures.

\section{Information about the author:}

Petkov S. V.

Doctor of Juridical Sciences, Professor, Director at the Department of Regional Offices of the Secretariat of Ukrainian Parliament Commissioner for Human Rights 21/8, Instytutska str., Kyiv, Ukraine 